Six ways to build circular business models

Bocken Nancy, Ritala Paavo

This is a Author's accepted manuscript (AAM) version of a publication

published by Emerald Publishing Limited

in Journal of Business Strategy

DOI: $10.1108 / J B S-11-2020-0258$

Copyright of the original publication: ( 2021 , Emerald Publishing Limited

Please cite the publication as follows:

Bocken, N. and Ritala, P. (2021), "Six ways to build circular business models", Journal of Business Strategy, Vol. ahead-of-print No. ahead-of-print. https://doi.org/10.1108/ JBS-11-2020-0258

This is a parallel published version of an original publication. This version can differ from the original published article. 


\title{
Six ways to build circular business models
}

\author{
Nancy Bocken \\ Maastricht Sustainability Institute \\ Maastricht University, Maastricht, The Netherlands
}

\author{
Paavo Ritala* \\ School of Business and Management \\ LUT University, Lappeenranta, Finland \\ *corresponding author: ritala@lut.fi \\ Published online in Journal of Business Strategy (2021) \\ DOI: 10.1108/JBS-11-2020-0258 \\ Deposited under CC BY-NC 4.0; \\ Any reuse is allowed in accordance with the terms outlined by the license.
}

\begin{abstract}
Purpose: Circular business models can improve resource use in a financially and environmentally feasible way. However, companies struggle to choose among the vast variety of ways to achieve circularity within a business model. The purpose of this paper is to offer a pragmatic guide for making strategic decisions on circular business models.
\end{abstract}

Design/methodology/approach: This paper develops a conceptual model of six different strategic approaches to circular business models and provides examples to business cases and practice to illustrate these.

Findings: This study identifies two critical strategy choices companies should make. First, an innovation strategy addresses the extent to which circularity is achieved with internal or external stakeholders. Second, a resource strategy addresses how companies achieve circularity by narrowing, slowing or closing resource loops. Using examples from business practice, this study illustrates how the combinations of these two strategies can be used to design competitive circular business models. Key managerial questions are also identified to help decide upon a feasible strategy for circular business model innovation.

Originality: While different types of circular business models have been described, it is less clear what the strategic choices are that companies need to make in order to find feasible business cases for circularity in terms of value proposition, value creation and delivery, and value capture. This study outlines these through a 'circular business model strategy framework'.

Keywords: circular economy; business model; busines model innovation; open innovation; collaboration; closed innovation; strategy 


\section{Introduction}

The circular economy is a new economic paradigm that aims to break free from the destructive and wasteful industry practices dependent on high sales volumes and fast-paced consumption. This change will eventually affect every industry and company, posing a major challenge for both startups and incumbents to develop new types of circular business models that are both financially but also ecologically feasible. Our study aims to provide a strategic decision-making framework that can be used to create or renew business models that draw from circular economy principles.

To respond to the rising demand for circularity, companies have developed different types of circular business models (Ferasso et al., 2020) that deliver superior customer value propositions, while resolving resource issues and combatting the dominant linear 'take-make-dispose' business model (Bocken et al., 2016). These are not just beneficial for society and environment, but also make a good business case. First, people have grown more aware of environmental aspects and increasingly view environmental issues as part of their consumption and employment choices. Second, regulators are focusing on circular economy with differences across institutional contexts, gradually providing incentives and enforcement toward circularity (Ranta et al., 2018). For instance, the EU has adopted a new 'EU Circular Economy Action Plan' focused on a cleaner and more competitive Europe (European Commission, 2020). In the USA, there are various circular economy policies at a city and sectorial level (see e.g. United States Chamber of Commerce Foundation, 2015). Finally, the circular economy can be a source of innovation and new revenues, particularly when a suitable business model is found (Hopkinson et al., 2018). Yet, there is a need for clear strategic guidelines of how existing and new companies can launch circular business model initiatives.

We suggest starting with two critical strategic choices: the innovation strategy and the resource strategy. As for the innovation strategy, firms need to choose to which extent they aim to improve circularity in their business models by firm-driven internal processes, by collaborative processes with external stakeholders, or both. These choices correspond to the idea of closed vs. open innovation (Chesbrough, 2003). These models of innovating circularity provide different benefits and challenges (Brown et al., 2019). As for the resource strategy, firms need to decide which type of circularity they pursue: narrowing, slowing, or closing resource loops (Bocken et al., 2016). We will next discuss a combination of choices that result in a $2 \times 3$ matrix of different strategic approaches to circular business models. 


\section{Circular business models: What are the feasible resource and innovation strategies?}

\subsection{Resource strategy}

Resource strategy refers to the environmental goals of the circular business model: narrowing, closing, or slowing resource loops (see Bocken et al., 2016).

Narrowing the loop focuses on efficiencies in design and production processes, for example, when a product is manufactured using fewer resources (i.e., energy, water, material), facilitated through cleaner production processes and better product design (e.g. by reducing packaging). This strategy is already prevalent in the current 'linear' economy as it often saves costs while saving resources. Companies should pursue this strategy regardless of their overall business model, given that improvements in technologies and processes allow them to do more with less. These efficiency gains should naturally not be done by sacrificing quality or customer value, however.

Closing loops refers to reusing material post-consumer usage and is often referred to as 'recycling'. For instance, precious metals collected from electronics may be reworked into a new batch of devices. When discarded materials are of inferior quality, they can be used for lower value purposes (e.g., insulation material) or worse, simply burned to generate energy, which is referred to as 'downcycling'. When a higher quality product is created - e.g. a quality piece of furniture from reclaimed wood - this is called 'upcycling' (McDonough and Braungart, 2013). Hence, the business case depends on the quality of the collected material and the end-product for which it is being used.

Slowing loops refers to extending the product life, so the product remains at its highest value for a long time. The idea is well-described by former eBay CEO John Donahoe who argued that "the greenest product is the one that already exists" (Bocken et al., 2016, p. 310). Consider any product lasting for a lifetime and slowing down the need to source new raw materials. This strategy is focused on product quality and durability (and, possibly, upgradability, e.g. for electronics) and involves strategies of maintenance and repair. Service models may involve strategies to extend the product lifetime. For example, 'power by the hour' established by Rolls-Royce already in 1962 involved a "complete engine and accessory replacement service" (...) "on a fixed-cost-per-flying-hour basis" (Rolls Royce, 2020). Airbus offer maintenance packages such as 'Flight Hour Services' (Airbus, 
2020). In second-hand, vintage and flea-markets used consumer products are re-sold after potential cleaning and repairing.

These three strategies are not mutually exclusive and are rather compatible. For example, a product may be produced using cleaner production processes (narrowing the loop), using recycled materials (closing the loop) and in a way that the product is durable and that services allow for a long product lifetime (slowing the loop). Moreover, slowing of loops might be later complemented with a business model that allows for closing the loop, e.g. when the material from a high-quality product that is eventually abandoned is adopted as a source for new value creation elsewhere.

\subsection{Innovation strategy}

Innovation strategy refers to the classic division between "closed" and "open" innovation, and in the context of our study, to the openness of the developed business model in question (Chesbrough and Appleyard, 2007).

A closed innovation strategy in relation to a circular business model is about organizing the circularity principles within the boundaries of the firm. This refers to, for example, internal resource reuse and improvements in quality of the products, making them last longer. Company-driven initiatives to encourage customers to return used products is an example of closed innovation. Companies pushing circularity with a closed innovation strategy benefit from keeping the circular process under their own control. This is beneficial in many ways, including close monitoring of resource efficiency, reuse and recycling, but also possibility to directly reap the economic benefits of these activities.

An open innovation strategy in the context of circular business models refers to connecting with external partners or customer and user communities to boost the circularity of the business model. Examples include engagement with communities and platforms that sell the firms' products in second-hand markets such as the selling of vintage and used Patagonia gear in Asos Marketplace. Alternatively, firms can also establish industrial-scale circular operations in energy and resource use, as recently witnessed with regional data center heat reuse schemes (Kokoulina et al., 2019). Open innovation for circularity provides benefits such as rapid scale-up of material reuse, as well as new ways to use excess resources in other organizations. The challenge from open models is the loss of control over the whole process and related relational and organizational coordination costs and risks. 


\section{Six strategy archetypes for circular business models}

To help deal with the managerial challenge of choosing the right way to approach circularity, we develop a conceptual model that supports the development of circular business model innovations (Figure 1). The 'circular business model strategy framework' represents two critical aspects of circular business model innovation: the resource strategy and the innovation strategy. Within each of the cells in the framework, we identify the key aspects of circular business models according to the value proposition (what value is provided and to whom; see e.g. Ranta et al., 2020), and the classic business model components (e.g. Teece, 2010) of value creation and delivery (how is the value provided?) and value capture (how does the company make money and capture other forms of value?). 


\section{Resource strategy}

\begin{tabular}{|c|c|c|}
\hline Narrowing loops & Slowing loops & Closing loops \\
\hline Open-narrowing & Open-slowing & Open-closing \\
\hline $\begin{array}{l}\text { Value proposition (example): } \\
\text { Reduce waste and resources in design and } \\
\text { production processes }\end{array}$ & $\begin{array}{l}\text { Value proposition (example): } \\
\text { Reuse resources to broaden the offerings to } \\
\text { the customer (e.g. vintage, second-hand) }\end{array}$ & $\begin{array}{l}\text { Value proposition (example): } \\
\text { A circular offering which involves lower } \\
\text { environmental footprint and resource burden }\end{array}$ \\
\hline $\begin{array}{l}\text { Value creation and delivery: Reduce cost } \\
\text { and negative impact through new } \\
\text { technologies and processes in collaboration }\end{array}$ & $\begin{array}{l}\text { Value creation and delivery: Create value } \\
\text { by connecting internal and external resource } \\
\text { flows via generative models }\end{array}$ & $\begin{array}{l}\text { Value creation and delivery: } \\
\text { Combine resource flows from external } \\
\text { ecosystem into customer offerings }\end{array}$ \\
\hline $\begin{array}{l}\text { with suppliers, customers and others } \\
\text { Value capture logic: } \\
\text { Save cost and resources }\end{array}$ & $\begin{array}{l}\text { Value capture logic: } \\
\text { Increase the number of transactions in an } \\
\text { ecosystem via reuse of products }\end{array}$ & $\begin{array}{l}\text { Value capture logic: } \\
\text { Lower the cost of resources used in customer } \\
\text { offerings, improve brand and corporate image }\end{array}$ \\
\hline $\begin{array}{l}\text { ase examples: } \\
\text { dustry collaboration on cleaner } \\
\text { frigeration technology; Sony and } \\
\text { amsung collaboration on LCD efficiency }\end{array}$ & $\begin{array}{l}\text { Case examples: } \\
\text { H\&M - Sellpy collaboration on second-hand } \\
\text { clothes market; iFixit repair platform; Res } Q \\
\text { Club excess food sales model }\end{array}$ & $\begin{array}{l}\text { Case examples: } \\
\text { Interface Networks for 'circular carpets' with } \\
\text { ZSL, Aquafil and fishery communities; JLR } \\
\text { and Novelis closing the aluminum loop }\end{array}$ \\
\hline Closed-narrowing & & sing \\
\hline $\begin{array}{l}\text { lue proposition (example): } \\
\text { duce waste and resources in design and } \\
\text { oduction processes }\end{array}$ & $\begin{array}{l}\text { Value propos } \\
\text { High quality pr } \\
\text { value }\end{array}$ & $\begin{array}{l}\text { Value proposition (example): } \\
\text { Connect with customers by using, recovering, } \\
\text { and maintaining post-consumer materials }\end{array}$ \\
\hline $\begin{array}{l}\text { Value creation and delivery : Reduce cost } \\
\text { and negative impact through internal } \\
\text { echnology, process and design innovations }\end{array}$ & $\begin{array}{l}\text { Value creation and delivery : } \\
\text { Long lasting design, repair services; } \\
\text { more value from less resources }\end{array}$ & $\begin{array}{l}\text { Value creation and delivery : } \\
\text { Increase customer retention and repurchases } \\
\text { via take-back plans }\end{array}$ \\
\hline $\begin{array}{l}\text { Value capture logic: } \\
\text { Save cost and resources }\end{array}$ & $\begin{array}{l}\text { Value capture logic: } \\
\text { Price premium through achieving quality } \\
\text { leadership and customer loyalty; create } \\
\text { value from same product multiple times }\end{array}$ & $\begin{array}{l}\text { Value capture logic: } \\
\text { Resource efficiency, improve brand and } \\
\text { reputation, reduce cost for materials }\end{array}$ \\
\hline $\begin{array}{l}\text { Case examples: } \\
\text { Companies like Apple minimising packaging } \\
\text { and using recycled materials; McDonald's' } \\
\text { 'fried for fuel" }\end{array}$ & $\begin{array}{l}\text { Case examples: } \\
\text { Long-life warrantees; hotel linen rental } \\
\text { services focused on product longevity }\end{array}$ & $\begin{array}{l}\text { Case example: } \\
\text { Take-back, rental and lease models to } \\
\text { recover the company's own materials such } \\
\text { as MUD Jeans Lease and Philips pay per lux }\end{array}$ \\
\hline
\end{tabular}

Figure 1 Circular business model strategy framework 


\subsection{Closed-narrowing: save cost and resources internally}

Closed-narrowing is perhaps one of the most common industry practices where value creation is about saving resources and cost using various types of innovation within the company boundaries. Value capture takes place via direct cost savings, and using these savings often contributes also to the symbolic aspects of customer value proposition by signaling the environmentally sustainable products and processes. First, there are several opportunities such as using combined heat and power and heat recovery to reduce energy use, but also the direct reuse of manufacturing waste or scraps within factory boundaries. A second example is light-weighting and reducing materials used per product. Many consumer product giants such as Apple have sought to minimize packaging per product and increasing the recycled content of the packaging. A third example is internal industrial symbiosis, where one 'waste' is used as a resource for another process within the same company (Zhu et al., 2007). For example, in 2006, McDonald's launched "fried for fuel" to produce biodiesel from fried oil generated in its restaurants, powering company trucks and reducing disposal fuel costs (Albino and Fraccascia, 2015).

\subsection{Open-narrowing: collaborative efficiency}

Open-narrowing is about collaborations, often on new technology and processes, to reduce the environmental impact associated with products and production processes. Companies capture value by saving in costs and resources and creating value propositions that communicate the reduction in material use to the increasingly ecological-aware end customers and stakeholders. However, value creation takes place across company boundaries, where various types of collaboration are used to reduce the material and resource use. A cross-industry example is the Consumer Goods Forum, a membership organization which facilitates collaboration, e.g. on phasing out hydrofluorocarbons (HFCs) from refrigeration (The Consumer Goods Forum, 2020). Another example is horizontal industry collaboration (or "coopetition") among manufacturers to improve the resource efficiency in their processes (see e.g. Christ et al., 2017).

\subsection{Closed-slowing: live with less that lasts longer}

Closed-slowing is about creating more value from less resources by focusing on long lasting design and services, developed in-house. Value propositions typically involve high quality offerings, increasing customer satisfaction and loyalty. This allows companies to capture value by price premiums by virtue of quality leadership. A typical example is to develop long-lasting products and offer customers warrantees and repair and maintenance services. A range of companies selling anything from outdoor gear, to cookware, socks and furniture, are offering some form of lifetime 
warrantee to help extend the lifetime of products and slow the loop. The cost of additional services and warrantees are typically borne by the company through a relatively higher price. Closed-slowing might also involve a different sales model. For example, furniture company Vitsœ focuses on design that allows people to "live with less that lasts longer". Part of this strategy involves no sales commissions, bonuses or discounts. A case on Vitsœ study suggests that the business has been financially viable despite its unconventional sales strategy (Bocken and Short, 2016). Slowing the loop can also be facilitated by a service model. For instance, rental models allow for the product to be reused over time. In the case of car rental, it is in the interest of the car rental company to ensure that the car gets repaired and maintained. The same is true for hotel linen and workwear rental services where the product remains in the ownership of the service provider who is incentivized to look after the product so it can be reused over and over.

\subsection{Open-slowing: collaborative product stewardship}

Open-slowing creates value by extending the product life by partnering and developing innovative solutions in collaboration with external stakeholders. The value propositions focus on reuse of products over time with new customers, which allows companies to capture value from the increasing number of transactions from the same products. At best, the business interests of partners and ecosystem members are combined with a circular flow of material that warrants extended usability for an offering. H\&M, for example, started to partner with (and in 2019 bought a majority stake in) second-hand online seller Sellpy to encourage clothing reuse. Another example is the iFixit community, which includes 'repair guides for everything, written by everyone'. Whereas repair information is freely available, the company earns revenues through selling parts and tools for repair. Finally, Finnish scale-up company ResQ Club enables luncheons to sell excess food to the users of the ResQ Club platform for reduced prizes, thus redistributing good food so it does not go to waste (Mattila et al., 2020).

\subsection{Closed-closing: continuous material reuse}

Closed-closing strategies appear quite similar to the closed-narrowing category, but the main difference is that 'closed-closing' creates value via post-consumer recovered materials while closednarrowing occurs at the 'pre-consumer stage' (e.g. reusing metals scraps within factory boundaries). Closed-closing takes place within company boundaries, and allows company to offer value propositions that rely on resource recovery from consumers or business customers in various ways. This enables capturing value by both efficiency and cost saving. As a closed-closing example, the business model of the company allows for recovery of the materials, and fully closing the loop after 
consumer (or another business in the case of B2B businesses) has used the offering. The jeans company MUD Jeans (mudjeans.eu) for example offers a leasing and take-back model for its jeans, so that the materials can be recovered and used again for new pairs of jeans and other clothing. In the case of the Philips' pay per lux model, used in offices and at airports, it provides light as a service, Philips retains ownership of the lights so these can be recycled in the end (Kramer et al., 2019).

\subsection{Open-closing: reducing waste via external ecosystem integration}

Open-closing creates value by bringing resources from external ecosystems and reconnecting those in different ways into customer offerings. The value proposition typically involves a product with a lower environmental footprint and lower resource burden. This allows capturing value by saving in resources as well as improving company brand and image among customers. A collaboration between the Zoological Society of London, Interface (carpet manufacturer), Aquafil (yarn manufacturer) and local communities in the Philippines led to the clean-up of discarded fishing nets which were turned into new carpets (Bocken et al., 2018). In the automotive industry and open-closing example is the collaboration between Jaguar Land Rover and its aluminum supplier Novelis to close the aluminum loop. Close collaboration was needed to collect offcuts and scrap from manufacturing and have it reprocessed and reshipped to the factory. Since 2011, the company has increased its recycled inputs from $33 \%$ to nearly $50 \%$ and continues to pursue this goal, as recycled aluminum requires up to $95 \%$ less energy during production than virgin material (Cambridge Institute for Sustainability Leadership, 2020).

\section{Conclusion}

Circular business models are increasingly pursued by companies, but managers face the challenge of navigating the many possibilities. This study brings clarity to this rapidly evolving area via the 'circular business model strategy framework' (Figure 1), which introduces six strategic approaches to circular business model innovation. These are built on the resource strategies of narrowing, closing or slowing loops (Bocken et al., 2016), closed or open strategies for innovation (Chesbrough and Appleyard, 2007) and business model and value proposition literature (Teece, 2010; Ranta et al., 2020).

There are many ways to achieve circularity in business models, as demonstrated by the six strategies. Both closed and open approaches are available, but each approach has distinct benefits and downsides. Closed approaches allow firms to maintain control over the coordination of the whole 
circular process, leading to less uncertainty and better control over the value capture. Ideally, all material and resource flows are circulated and processed inhouse which maximizes the material efficiency in the local context. However, retrieving and processing material would require a change in processes, both at the physical (take-back) and financial and accounting levels. Open approaches, allow companies to flexibly bring in new capabilities such as product return services for refurbishing and repair and maintenance services, building on user and producer ecosystems. Yet, over time, it may be beneficial to develop these capabilities inhouse when the new business model becomes more important to the business. Therefore, companies need to make critical choices over which strategies to follow when pursuing circularity. Each strategy involves specific benefits and risks. Therefore, we outlined key questions that managers need to develop circularity in their business model (Table 1).

Table 1. Key managerial questions to decide upon a strategy for circular business model innovation

\begin{tabular}{|c|c|c|c|}
\hline & Narrowing loops & Slowing loops & Closing loops \\
\hline $\begin{array}{l}\text { Open business } \\
\text { model } \\
\text { innovation }\end{array}$ & $\begin{array}{l}\text { Which of our current } \\
\text { ecosystem partners are ready } \\
\text { to improve their resource } \\
\text { efficiency together with us? } \\
\text { Are there new horizontal or } \\
\text { vertical collaborations that we } \\
\text { can initiate to boost resource } \\
\text { and material efficiency? }\end{array}$ & $\begin{array}{l}\text { Can we create digital platforms or } \\
\text { partner with platform providers } \\
\text { that allow for reusing and sharing } \\
\text { of valuable resources among } \\
\text { customers? } \\
\text { What is our own added value to } \\
\text { such ecosystems? } \\
\text { Can we build on an existing } \\
\text { customer base or do we need to } \\
\text { attract new customers? }\end{array}$ & $\begin{array}{l}\text { Are there existing producers of } \\
\text { leftover material that is valuable } \\
\text { but currently underutilized? } \\
\text { Can we create external } \\
\text { ecosystems that collect such } \\
\text { materials? } \\
\text { Can we bundle these materials } \\
\text { into competitive customer value } \\
\text { propositions? }\end{array}$ \\
\hline $\begin{array}{l}\text { Closed business } \\
\text { model } \\
\text { innovation }\end{array}$ & $\begin{array}{l}\text { How can we minimize } \\
\text { resource usage in internal } \\
\text { processes? } \\
\text { Are we able to build on those } \\
\text { resource savings to generate } \\
\text { concrete cost savings? } \\
\text { Are we able communicate } \\
\text { those efficiencies to } \\
\text { customers and business } \\
\text { partners? }\end{array}$ & $\begin{array}{l}\text { Can we create a well-functioning } \\
\text { repair or refurbishment } \\
\text { organization and offering to serve } \\
\text { existing customers better? } \\
\text { Are we able to take a risk of long } \\
\text { warranties? } \\
\text { Can we charge customers } \\
\text { premium prices in exchange for } \\
\text { product longevity? }\end{array}$ & $\begin{array}{l}\text { Can we identify valuable ways to } \\
\text { take back products from our } \\
\text { existing customers and use it as } \\
\text { an input in the same or different } \\
\text { products? } \\
\text { Can we design a win-win take- } \\
\text { back or repurchase scheme with } \\
\text { our customers? } \\
\text { Can we use closed-loop processes } \\
\text { effectively in marketing and } \\
\text { branding? }\end{array}$ \\
\hline
\end{tabular}

After assessing the potential of the different strategies, companies should decide on the best configuration and roadmap to develop these approaches. In fact, we have noticed that many leading companies combine several approaches within their business model. To begin with, innovation strategies are at their best when they combine the best features of closed and open innovation (Dąbrowska et al., 2019), and this is very much true for circular business models. Companies need 
not settle for just one strategy within the six possibilities identified in this study. Instead, many circular economy trailblazers are combining several - if not all - six ways to build circular business models. Patagonia, for example, incorporates several circular business strategies, from using recycled material content to close the loop and establishing a second-hand clothing platform to slow the loop, on top of all kinds of efficiencies in design and production to narrow the loop. While some of their initiatives are done inhouse, the second-hand platform was initially a collaboration with eBay. Similarly, consumer goods manufacturers, urged by increasing consumer interests and policies, need to find every means to reduce plastic waste, leading to developing of circular business models across all dimensions of our framework.

To conclude, we propose that for organizations to transition to a circular business model, they need to consider both their resource and innovation strategies. The decision whether to close, slow and narrow the loop is combined with a consideration to do these attempts alone, or work with others. This decision depends on the availability of internal capabilities and whether the new circular business activity (e.g. returns of used products, repairs) will be a core and significant part of the business model. Here, the classic decision of make-buy-partner needs to be considered together with the assessment of the circular economy benefits (or downsides) that the different organizing models allow. Furthermore, organizing decisions are certainly not static, and they will evolve as the business model matures. For instance, a company might begin by honing the internal processes, and then moving to generate a larger impact on its supply chain partners, user ecosystems, and ultimately even the whole industries. However, the voyage needs to start somewhere. In this regard, the six strategies should provide support for managers in the business transformation towards the circular economy. 


\section{References}

Airbus. (2020), “Airbus Flight Hour Services", Available at:

https://www.airbus.com/newsroom/stories/airbus-flight-hour-services--optimising-customeraircraft-operat.html (accessed 22 June 2020).

Albino, V., and Fraccascia, L. (2015), “The industrial symbiosis approach: A classification of business models", Procedia Environmental Science, Engineering and Management, 2(3), 217-223.

Bocken, N. M., De Pauw, I., Bakker, C., and Van Der Grinten, B. (2016), "Product design and business model strategies for a circular economy", Journal of Industrial and Production Engineering, 33(5), 308-320. https://doi.org/10.1080/21681015.2016.1172124

Bocken, N. M., and Short, S. W. (2016), “Towards a sufficiency-driven business model: Experiences and opportunities", Environmental Innovation and Societal Transitions, 18, 41-61. https://doi.org/10.1016/j.eist.2015.07.010

Bocken, N. M., Schuit, C. S., and Kraaijenhagen, C. (2018), "Experimenting with a circular business model: Lessons from eight cases", Environmental Innovation and Societal Transitions, 28 , 79-95. https://doi.org/10.1016/j.eist.2018.02.001

Brown, P., Bocken, N., and Balkenende, R. (2019), "Why do companies pursue collaborative circular oriented innovation?", Sustainability, 11(3), 635. https://doi.org/10.3390/su11030635

Cambridge Institute for Sustainability Leadership (2020), “A circular economy case study Collaboration for a closed-loop value chain Transferable learning points from the REALCAR project", Available at: https://www.cisl.cam.ac.uk/resources/publication-pdfs/cisl-closed-loop-casestudy-web.pdf (accessed 18 June 2020).

Chesbrough, H. W. (2003), Open innovation: The new imperative for creating and profiting from technology. Harvard Business Press.

Chesbrough, H. W., and Appleyard, M. M. (2007), “Open innovation and strategy”, California Management Review, 50(1), 57-76. https://doi.org/10.2307/41166416 
Christ, K. L., Burritt, R. L., and Varsei, M. (2017), "Coopetition as a potential strategy for corporate sustainability", Business Strategy and the Environment, 26(7), 1029-1040.

https://doi.org/10.1002/bse.1967

Consumer Goods Forum (2020), "Refrigeration: Taking action to mobilise resources to phase out high GWP refrigerants", Available at: https://www.theconsumergoodsforum.com/environmentalsustainability/refrigeration/ (accessed 10 August 2020)

Dąbrowska, J., Lopez-Vega, H., and Ritala, P. (2019), "Waking the sleeping beauty: Swarovski's open innovation journey”, $R \& D$ Management, 49(5), 775-788. https://doi.org/10.1111/radm.12374

European Commission. (2020), EU Circular Economy Action Plan. A new Circular Economy Action Plan for a Cleaner and More Competitive Europe. Available at:

https://ec.europa.eu/environment/circular-economy/ (accessed 22 June 2020).

Ferasso, M., Beliaeva, T., Kraus, S., Clauss, T., and Ribeiro-Soriano, D. (2020), “Circular economy business models: The state of research and avenues ahead", Business Strategy and the Environment. https://doi.org/10.1002/bse.2554

Hopkinson, P., Zils, M., Hawkins, P., and Roper, S. (2018), "Managing a complex global circular economy business model: opportunities and challenges", California Management Review, 60(3), 71-94. https://doi.org/10.1177/0008125618764692

Kokoulina, L., Ermolaeva, L., Patala, S., and Ritala, P. (2019), "Championing processes and the emergence of industrial symbiosis", Regional Studies, 53(4), 528-539. https://doi.org/10.1080/00343404.2018.1473568

Kramer, M. R., Geradts, T., and Nadella, B. (2019), Philips Lighting: Light-as-a-Service. Harvard Business School Case 719-446, March 2019. (Revised May 2019.)

Mattila, M., Mesiranta, N., and Heikkinen, A. (2020), "Platform-based sustainable business models: reducing food waste in food services", International Journal of Entrepreneurship and Innovation Management, 24(4-5), 249-265. https://doi.org/10.1504/IJEIM.2020.108258 
McDonough, W., and Braungart, M. (2013), The upcycle: Beyond sustainability--designing for abundance. Macmillan.

Ranta, V., Aarikka-Stenroos, L., Ritala, P., and Mäkinen, S. J. (2018), "Exploring institutional drivers and barriers of the circular economy: A cross-regional comparison of China, the US, and Europe", Resources, Conservation and Recycling, 135, 70-82.

https://doi.org/10.1016/j.resconrec.2017.08.017

Ranta, V., Keränen, J., and Aarikka-Stenroos, L. (2020), "How B2B suppliers articulate customer value propositions in the circular economy: Four innovation-driven value creation logics", Industrial Marketing Management, 87, 291-305. https://doi.org/10.1016/j.indmarman.2019.10.007

Rolls Royce. (2020), “Rolls-Royce celebrates 50th anniversary of Power-by-the-Hour”, Available at: https://www.rolls-royce.com/media/press-releases-archive/yr-2012/121030-the-hour.aspx (accessed 22 June 2020).

Teece, D. J. (2010), “Business models, business strategy and innovation”, Long Range Planning, 43(2-3), 172-194. https://doi.org/10.1016/j.lrp.2009.07.003

United States Chamber of Commerce Foundation. (2015), “Achieving a circular economy: how the private sector is reimaginging the future of business", Available at:

https://www.uschamberfoundation.org/sites/default/files/Circular\%20Economy\%20Best\%20Practic es.pdf (accessed 29 June 2020);

Zhu, Q., Lowe, E. A., Wei, Y. A., and Barnes, D. (2007), "Industrial symbiosis in China: a case study of the Guitang Group", Journal of Industrial Ecology, 11(1), 31-42.

https://doi.org/10.1162/jiec.2007.929 